\title{
The effect of trichloroacetamide, chloroform and linseed oil given into the rumen of sheep on some of the end-products of rumen digestion
}

\author{
BY J. L. CLAPPERTON \\ The Hannah Research Institute, Ayr $K A 6{ }_{5} \mathrm{HL}$ \\ (Received 17 September 1973 - Accepted 7 November 1973)
}

\begin{abstract}
I. Twelve sheep were offered a diet of hay and molassed sugar-beet pulp for 18 weeks, and from the 3 rd to the 16 th week the sheep were divided into four groups of three; one of each of the groups received daily $170 \mathrm{mg}$ trichloroacetamide, $140 \mathrm{mg}$ chloroform, $30 \mathrm{~g}$ linseed oil or no additive.

2. The additives had no significant effect on the apparent digestibility of the dry matter, organic matter, nitrogen or energy of the diet.

3. When either trichloroacetamide or chloroform was added to the diet, methane production was almost totally suppressed and some hydrogen was produced but, although these changes persisted with chloroform, they were much reduced after $28 \mathrm{~d}$ of trichloroacetamide administration. When linseed oil was added to the diet the methane production was reduced by almost I $5 \%$.

4. Each additive caused a significant reduction in the concentration of total volatile fatty acids in the rumen liquor and in the molar proportion of acetic acid in the total volatile fatty acids, with a corresponding increase in the molar proportion of propionic acid. The effect was greatest immediately after the introduction of the compound into the diet but it diminished and appeared to attain a stable value within the experimental period of $98 \mathrm{~d}$. diet.

5. All the effects disappeared within $14 \mathrm{~d}$ of the withdrawal of the compounds from the

6. It is suggested that these effects may be the result of selective effects on the rumen microflora and that further work is needed to find an additive whose effects are persistent.
\end{abstract}

When trichloroacetamide (Trei, Parish, Singh \& Scott, 197I), chloroform (Clapperton \& Czerkawski, 1972), linseed oil (Czerkawski, Blaxter \& Wainman, 1966) or a hemi-acetal of chloral hydrate and starch (Trei, Scott \& Parish, 1972) were introduced into the rumen of sheep for periods of up to $14 \mathrm{~d}$, the methane production and the molar proportion of acetic acid in the rumen liquor were reduced, the molar proportion of propionic acid in the rumen liquor was increased, and the molar proportion of butyric acid was unchanged. With both trichloroacetamide and chloral hydrate-starch it was shown that, after $90 \mathrm{~d}$ of continuous administration of these compounds to sheep, the reduction in the methane production was less marked than after $14 \mathrm{~d}$ administration and, while the molar proportion of acetic acid in the rumen liquor was still reduced, the molar proportion of propionic acid had returned to its original value and the molar proportion of butyric acid was increased (Trei et al. r971; Trei et al. 1972).

If these compounds are to be used to increase the proportion of the food energy retained by reducing the methane energy loss, then it is necessary to show that the effects are persistent. 'This experiment was designed to measure the effect of adding such compounds to the rumen of sheep continuously for 3 months. 
EXPERIMENTAL

Sheep. Twelve 2-year-old castrated male Down $\times$ Greyface sheep were used in the experiment. They weighed approximately $45 \mathrm{~kg}$ and each was fitted with a permanent rumen cannula. At the beginning and the end of the experiment each sheep was offered the control diet for $x_{4} \mathrm{~d}$; during the middle part of the experiment $\left(9^{8} \mathrm{~d}\right.$ ) three sheep were allocated to each experimental diet. The whole experiment lasted $126 \mathrm{~d}$. Thus, for any one sheep, the sequence of feeding was $14 \mathrm{~d}$ on the control diet, $98 \mathrm{~d}$ on the experimental diet and a further $\mathrm{I} 4 \mathrm{~d}$ on the control diet.

Food. Food was offered to the animals in two equal amounts at 10.00 and 22.00 hours. The animals were given a mixture of chopped hay $(400 \mathrm{~g} / \mathrm{kg})$ and molassed sugar-beet pulp $(600 \mathrm{~g} / \mathrm{kg})$. Sheep on the control, trichloroacetamide and chloroform diets were given $600 \mathrm{~g}$ food/d: to compensate for the higher calculated energy value of the linseed-oil diet, sheep given this diet were offered $584 \mathrm{~g}$ food/d. There were some food refusals during the experiment but these were usually less than $5 \%$ of each day's ration, and were not associated with any particular additive.

Additives. Trichloroacetamide $(472 \mathrm{mg} / \mathrm{kg})$ and linseed oil $(83 \mathrm{~g} / \mathrm{kg})$ were mixed with the sugar-beet pulp. Originally, it was also intended to mix the chloroform into the pulp, but when this was done, it was found that the effect on the animal's metabolism was markedly reduced. Presumably the chloroform either evaporated from the mixture or it was absorbed by the polythene bag in which the mixed food was stored. It was decided, therefore, to give the chloroform mixed with maize oil $(75 \mathrm{mg} / \mathrm{g})$ in a gelatin capsule containing I $\mathrm{g}$ of mixture. The capsule was inserted into the rumen through the fistula twice daily when the sheep was fed. The sheep received daily $170 \mathrm{mg}$ trichloroacetamide, $140 \mathrm{mg}$ chloroform or $30 \mathrm{~g}$ linseed oil. To compensate for the maize oil added with the chloroform, maize oil $(6 \mathrm{~g} / \mathrm{kg})$ was added to the sugar-beet pulp used in all diets.

Measurements. Samples of rumen liquor were collected on 2 consecutive days in alternate weeks of the experiment. Samples were taken at 08.30, I1.00, I2.30 and 16.00 hours. The amounts of volatile fatty acids were determined by the method of Cottyn \& Boucque (1968) using crotonic acid as the internal standard.

The gas production of the rumen liquor of the sheep was measured by the method described by Czerkawski \& Breckenridge (1970) using rumen liquor collected at I I. 00 hours on one day during each period. For the determination of apparent digestibility, faeces were collected for 5 consecutive days during the control periods and in every $4^{\text {th }}$ week during the treatment periods. These samples were pooled for the determination of dry matter, organic matter, nitrogen and energy by the methods described by Graham, Blaxter \& Armstrong (1958).

Statistical analysis. The results were analysed statistically by an analysis of variance (Snedecor, 1956) using the mean values for each sheep in each period. 
Table I. Composition of the diets used in the experiment (/kg dry matter)

\begin{tabular}{|c|c|c|c|}
\hline Diet & $\begin{array}{l}\text { Organic } \\
\text { matter } \\
(\mathrm{g})\end{array}$ & $\begin{array}{l}\text { Nitrogen } \\
\text { (g) }\end{array}$ & $\begin{array}{c}\text { Gross } \\
\text { energy } \\
(\mathrm{MJ})\end{array}$ \\
\hline Hay & 938 & $13 \cdot 6$ & $18 \cdot 69$ \\
\hline Molassed sugar-beet pulp & 921 & $18 \cdot 9$ & $\times 7 \cdot 39$ \\
\hline Molassed sugar-beet pulp + trichloroacetamide & 922 & $18 \cdot 8$ & 17.57 \\
\hline Molassed sugar-beet pulp for chloroform diet & 925 & I9.I & $17 \cdot 45$ \\
\hline Molassed sugar-beet pulp +linseed oil & 933 & 17.0 & 18.84 \\
\hline
\end{tabular}

Table 2. Apparent digestibility of dry matter, organic matter, nitrogen and energy during the first and last control periods and during some of the treatment periods

(Mean values for twelve sheep in control periods and for three sheep during the three treatment periods)

\begin{tabular}{|c|c|c|c|c|c|c|c|c|}
\hline & $\begin{array}{l}\text { Control } \\
\text { period I }\end{array}$ & $\underset{\text { treatment }}{\text { No }}$ & $\begin{array}{l}\text { Trichloro- } \\
\text { acetamide } \\
\text { added }\end{array}$ & $\begin{array}{l}\text { Chloro- } \\
\text { form } \\
\text { added }\end{array}$ & $\begin{array}{c}\text { Linseed } \\
\text { oil } \\
\text { added }\end{array}$ & $\begin{array}{l}\text { Control } \\
\text { period } 2\end{array}$ & $\begin{array}{l}\text { SE of } \\
\text { control } \\
\text { periods }\end{array}$ & $\begin{array}{c}\text { SE of } \\
\text { treatment } \\
\text { periods }\end{array}$ \\
\hline $\begin{array}{l}\text { Dry matter } \\
\text { Organic } \\
\text { matter }\end{array}$ & $\begin{array}{l}0.780 \\
0.767\end{array}$ & $\begin{array}{l}0.776 \\
0.762\end{array}$ & $\begin{array}{l}0.795 \\
0.782\end{array}$ & $\begin{array}{l}0.798 \\
0.786\end{array}$ & $\begin{array}{l}0.801 \\
0.790\end{array}$ & $\begin{array}{l}0.795 \\
0.782\end{array}$ & $\begin{array}{l}0.011 \\
0.010\end{array}$ & $\begin{array}{l}0.012 \\
0.008\end{array}$ \\
\hline $\begin{array}{l}\text { Nitrogen } \\
\text { Energy }\end{array}$ & $\begin{array}{l}0.677 \\
0.766\end{array}$ & $\begin{array}{l}0.678 \\
0.772\end{array}$ & $\begin{array}{l}0.702 \\
0.788\end{array}$ & $\begin{array}{l}0.717 \\
0.789\end{array}$ & $\begin{array}{l}0.719 \\
0.793\end{array}$ & $\begin{array}{l}0.703 \\
0.785\end{array}$ & $\begin{array}{l}0.016 \\
0.008\end{array}$ & $\begin{array}{l}0.017 \\
0.013\end{array}$ \\
\hline
\end{tabular}

\section{RESULTS}

Composition of the food used in the experiments. The mean proximate composition of the foods in the experiments is shown in Table I. There were no large differences between the diets except that the energy content of the molassed sugar-beet pulp and linseed-oil mixture was higher than that of the other diets. This difference was compensated for by the lower rate of feeding, and the energy intake of all the sheep was almost the same.

Apparent digestibility. The mean results for the apparent digestibility of the diets are shown in Table 2. Each control value is the mean of twelve sheep. The values for the different diets are the mean of three individual determinations at monthly intervals on each of three sheep. There were no statistically significant differences between either the different additives or the various determinations at different times during the experiment.

In vitro gas production. The mean volume of gas production in each period and the mean percentage of methane and hydrogen in the gas are shown in Fig. I. The total volume of gas produced during the incubation was highest during the first control period. After this period the gas production in animals given the control diet fell throughout the experiment, and the average value for all the sheep during the final control period was only $59 \%$ of the original value. No explanation can be offered for this fall in total gas production. Generally the volume of gas produced when the compounds were added to the rumen was statistically significantly $(P<0.01)$ less than that of the control diet, the average reductions during the $98 \mathrm{~d}$ of the experiment being: trichloroacetamide, $22 \%$; chloroform, $31 \%$; linseed oil, $14 \%$. The 


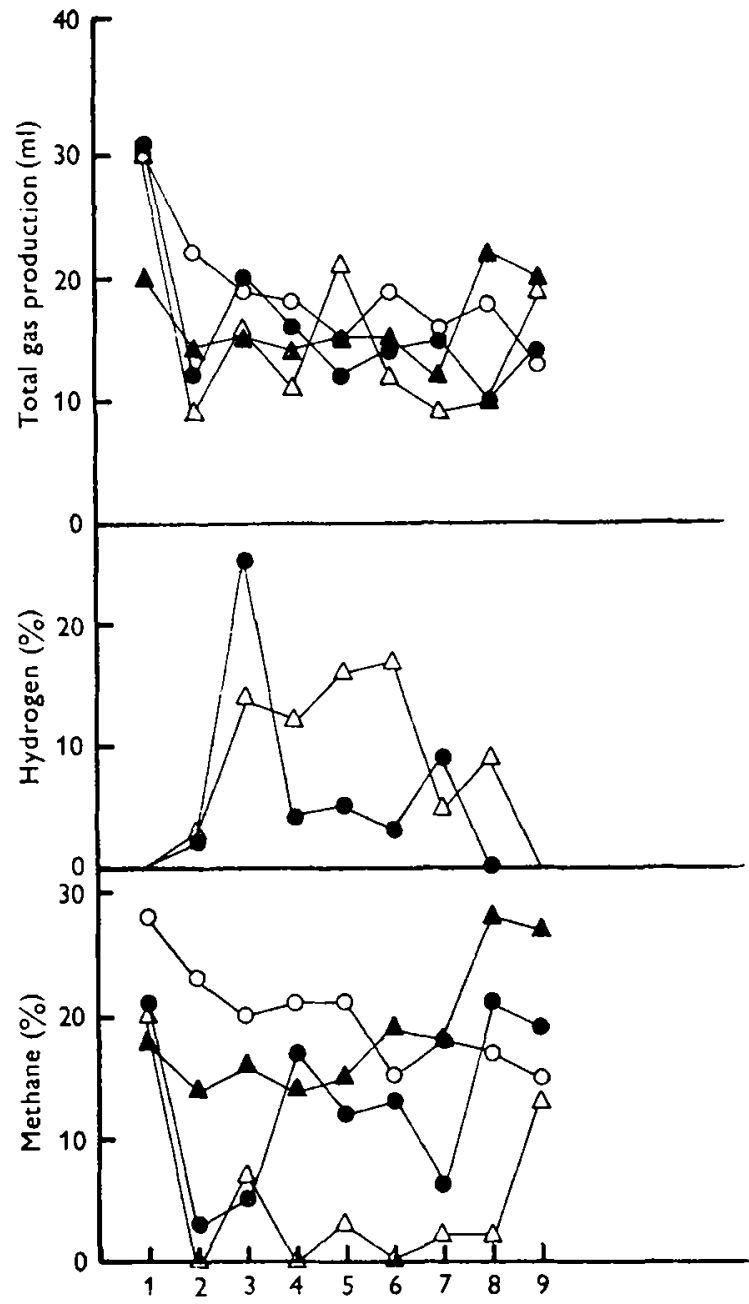

Fig. 1. The effect of adding trichloroacetamide (O), chloroform $(\Delta)$, or linseed oil $(\Delta)$ to a basal diet of molassed sugar-beet pulp $(O)$ on the total gas production and the proportion of methane and hydrogen in the gas of the rumen.

Table 3. Mean composition (molar \%) of volatile fatty acids in the rumen liquor of twelve sheep given various compounds into the rumen

Additive

None-begin

None

Trichloroacetamide

Chloroform

Linseed oil

None-end

SE of begin and end periods

SE of treatment periods
Acetic

647

$67 \cdot 5$

$6 \mathrm{I} \cdot 5$

$58 \cdot 8$

$64 \cdot 9$

$67 \cdot 3$

0.4

0.9
Propionic

$2 \mathrm{I} \cdot 6$

20.0

23.5

$25 \cdot 1$

23.0

$19 \cdot 1$

0.9

I'I
Butyric

II. 4

10.5

$12 \cdot 1$

I I. 9

$9 \cdot 3$

II. O

0.3

0.4
Isovaleric

0.6

0.7

0.9

$x \cdot 6$

$1 \cdot 0$

$I \cdot I$

$0 \cdot 1$

$0 \cdot 1$
Valeric

0.6

0.7

$1 \cdot 0$

$\mathrm{I} \cdot 8$

0.9

0.8

0.1

O'I 


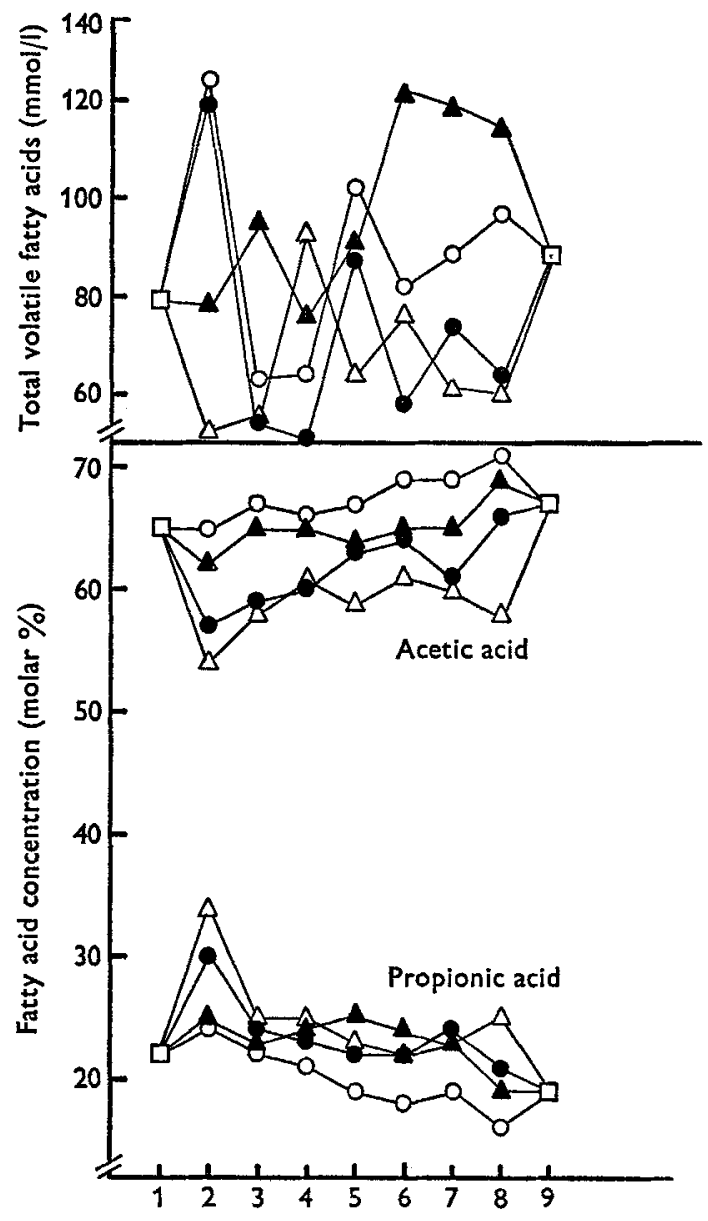

Fig. 2. The effect of adding trichloroacetamide ( $O$ ), chloroform $(\triangle)$, or linseed oil $(\Delta)$ to a basal diet of hay and molassed sugar-beet pulp (O) on the total volatile fatty acid concentration in the rumen liquor and on the molar proportion of acetic and propionic acids.

proportion of methane in the gas produced in the rumen of the control sheep fell throughout the experiment and no hydrogen was present in the gas. In the gas produced in sheep given trichloroacetamide, methane fell to less than $5 \%$ in the Ist month during which the additive was given, then it rose to an average of $13.6 \%$ during the remainder of the experiment. At the same time, the proportion of the gas present as hydrogen increased to $25 \%$ in the $2 \pi$ d period; during the remainder of the experiment the proportion of hydrogen in the incubation gas averaged $4 \%$. In sheep given chloroform, the proportion of methane in the gas was $7 \%$ during the 2 nd period, in periods 5,7 and 8 it was less than $4 \%$, and in periods 1,3 and 5 there was no methane at all. Hydrogen in periods $3-6$ inclusive averaged $14.7 \%$ and in the remaining periods it averaged $5.6 \%$. When linseed oil was added to the rumen, the proportion of methane in the fermentation gas was reasonably constant at $17.6 \%$ and there was no hydrogen. 
Rumen volatile fatty acids. The mean concentrations of volatile fatty acids in the rumen liquor during the treatment periods were $(\mathrm{mmol} / \mathrm{l})$ : no additive, $90 \cdot 4 \pm 2 \cdot 3$; trichloroacetamide, 70.9 $\pm 2 \cdot 3$; chloroform, $65 \cdot 3 \pm 2 \cdot 0$; linseed oil, $100 \cdot 3 \pm 5 \cdot 1$. The addition to the rumen of either trichloroacetamide or chloroform caused a statistically significant reduction $(P<0.0 \mathrm{I})$ in the total concentration of volatile fatty acids in the rumen liquor. The composition of the volatile fatty acids in each period of the experiment is shown in Fig. 2, and the mean values for the first and last control period and for the middle period of the experiment are shown in Table 3 . These mean values show that, on average, each additive reduced the molar proportion of acetic acid and increased the molar proportions of butyric acid, isovaleric and valeric acids. These effects were most marked when chloroform was added to the rumen, and were least so when linseed oil was added. Comparing the values for the control periods at the beginning and end of the experiment shows that the proportion of acetic acid in the rumen liquor rose during the course of the experiment while that of propionic acid fell. These effects are also shown in Fig. 2. This shows that the effects of both chloroform and trichloroacetamide were greatest in the first period of the experiment and that the difference between the control and additive values was less in subsequent periods but did not show any marked regular change with time.

\section{DISCUSSION}

In previous experiments (Clapperton \& Czerkawski, 1972), there was some indication that, although the differences were not statistically significant $(P<0.05)$, the apparent digestibility of energy in the diet of sheep was reduced from 0.57 to 0.56 . In these experiments, again there were no statistically significant effects on apparent digestibility but the actual values tended to be higher when trichloroacetamide, chloroform or linseed oil were added to the basal diet. It seems safe to conclude that these additives had no adverse effect on the apparent digestibility of the food.

All the additives reduced the methane production of the sheep. With linseed oil, the average reduction throughout the period of administration was $8 \%$, with trichloroacetamide it was $43 \%$ and with chloroform it was $89 \%$. With chloroform, suppression was relatively constant throughout the experiment but, with both linseed oil and trichloroacetamide, the effect on methane production was relatively large during the Ist month of administration and the effect then diminished as administration continued. After the administration was stopped, the methane production of all the sheep returned to normal within $14 \mathrm{~d}$. These changes indicate an adaptation of the rumen flora to trichloroacetamide and linseed oil. With trichloroacetamide, the rumen may be able to develop a deamination mechanism enabling it to convert trichloroacetamide into trichloroacetic acid and ammonia. It is known that trichloroacetic acid is not a methane-suppressing compound (J. W. Czerkawski, personal communication). With linseed oil, where the various changes are much smaller, the balance of the methanogenic bacteria may be altered in such a way as to allow a return to a normal methane production.

The concentration of total volatile fatty acids was significantly reduced $(P<0.01)$ 
by trichloroacetamide and by chloroform, but the addition of linseed oil to the diet had no effect. This is in agreement with previous results at this Institute (Clapperton \& Czerkawski, 1972). There were no marked changes in the concentration of total volatile fatty acids during the course of the experiment. All additives reduced the molar proportion of acetic acid in the volatile fatty acids and increased the molar proportion of propionic acid. The molar proportions of butyric, isovaleric and valeric acids, were all significantly increased (except the molar proportion of butyric acid when linseed oil was given), although the changes were not very large. With all the additives, however, the effect on the proportion of the volatile fatty acids was greatest immediately after the introduction of the additive and the effect then became less although it always persisted throughout the experiment. These changes probably reflect changes in the rumen microflora. Initially, the effect is very great on the bacteria normally responsible for the production of methane and of acetic acid. Later, however, either the same bacteria are able to develop a resistance to the effects of the additive or the changed conditions in the rumen enable other species to develop.

The results suggest that the persistence of the effects on the production of methane and of the volatile fatty acids depends on the additive used. If an additive is to be developed for practical feeding then the effect must persist over at least the fattening period of the animal concerned. Alternatively, if the additive is used in dairy cow rations, then the effect must last for the main part of the lactation. Further work is needed to find a suitable additive.

The author thanks Dr R. Waite for helpful advice and criticism, Dr P. C. Thomas for preparing the animals, and Mrs A. T. Cameron and Miss G. Breckenridge for skilled technical assistance.

\section{REFERENCES}

Clapperton, J. L. \& Czerkawski, J. W. (r972). Proc. Nutr. Soc. 31, 55A.

Cottyn, B. G. \& Boucque, C. V. (1968). F. agric. Fd Chem. 16, 105.

Czerkawski, J. W. \& Breckenridge, G. (1970). Lab. Pract. 19, 717.

Czerkawski, J. W., Blaxter, K. L. \& Wainman, F. W. (1966). Br. F. Nutr. 20, 485.

Graham, N. McC., Blaxter, K. L. \& Armstrong, D. G. (I958). Publs Eur. Ass. Anim. Prod. no. 8, p. 157.

Snedecor, G. W. (1956). Statistical Methods Applied to Experiments in Agriculture and Biology 5th ed. Ames, Iowa: Iowa State College Press.

Trei, J. E., Parish, R. C., Singh, Y. K. \& Scott, G. C. (197r). F. Dairy Sci. 54, 536.

Trei, J. E., Scott, G. C. \& Parish, R. C. (1972). F. Anim. Sci. 34, 510. 